\title{
Plagiarism, Parody, and Pastiche: Eliza Haywood writes back to Daniel Defoe and J. M. Coetzee
}

\author{
Laura Wright
}

Western Carolina University

\begin{abstract}
Through an examination of the politics of print culture that contributed to the 1740 continuation of Daniel Defoe's 1724 Roxana, this essay brings the historical $18^{\text {th }}$ century playwright, novelist, and political pamphleteer Eliza Haywood into conversation with South African novelist J.M. Coetzee's metafictional reworking of Defoe's Robinson Crusoe (1719) and Roxana, Foe (1986). This essay places Haywood - whose novel The British Recluse (1722) is one of at least seven preexisting texts that make up the "pastiche" (Seager, 2009, p. 370) that constitutes the 1740 Roxana - alongside Foe's narrator Susan Barton, a character who constitutes "a pastiche of $18^{\text {th }}$-century heroines" (Maher 39), a woman who is "doubt itself" (Coetzee 133), uncertain of who controls the truth of her narrative, yet a woman who writes back to and against the narrative established for her by her male counterparts. Susan's story of her life as a castaway on Cruso's island is taken from her by Foe, Coetzee's fictionalization of Daniel Defoe, who, instead of writing her requested The Female Castaway, writes her out of the narrative that becomes Robinson Crusoe, turning her instead into the narrator of Roxana. Spivak asks, "who is the female narrator of Robinson Crusoe?" And I answer: in a somewhat playful feminist act of resurrection, Eliza Haywood.
\end{abstract}

- "Who is this female narrator of Robinson Crusoe?" (Spivak, 1990, p. 7)

— "Who is speaking me?" (Susan Barton, J. M. Coetzee's Foe)

s Gayatri Spivak noted way back in 1990, South African author "[J.M.] Coetzee makes
the final episode of Defoe's novel Roxana flow into this citation of Robinson Crusoe" in
his 1986 novel Foe (1986, p. 8). But in Coetzee's novel, narrator and protagonist Susan
Barton resists Foe's attempts to place her into Roxana's story: in her own telling, Susan is a
mother whose only daughter is abducted two years prior to the narrative only to reappear as
Foe's creation- "father-born" (p. 91) - a girl Susan claims is not her child. And according to
Tisha Turk, "to say, as [Derek] Attridge does, that Susan's story 'becomes' Roxana is to miss
the extent to which Foe invents a different version of that story ... The intertextual blank,
then-the gap between Roxana and Foe-is better filled with a more complicated story: in 
addition to writing Susan out of Robinson Crusoe, Foe writes her into the role of whore" (304). Through an examination of the politics of print culture that contributed to the 1740 continuation of Daniel Defoe's 1724 Roxana, I want to bring the historical $18^{\text {th }}$-century playwright, novelist, and political pamphleteer Eliza Haywood into conversation with South African novelist J.M. Coetzee's metafictional reworking of Defoe's Robinson Crusoe (1719) and Roxana, Foe (1986). I want to place Haywood-whose novel The British Recluse (1722) is one of at least seven pre-existing texts that make up the "pastiche" (Seager, 2009, p. 370) that constitutes the 1740 Roxana-alongside Foe's narrator Susan Barton, a character who constitutes "a pastiche of $18^{\text {th }}$-century heroines" (Maher, p. 39), a woman who is "doubt itself" (Coetzee, p. 133), uncertain of who controls the truth of her narrative. Susan's story of her life as a castaway on Cruso's island is taken from her by Foe, Coetzee's fictionalization of Daniel Defoe. Instead of writing Susan's requested The Female Castaway, Foe writes her out of the narrative that becomes Robinson Crusoe, turning her instead into the narrator of Roxana. Spivak asks, "who is the female narrator of Robinson Crusoe?" And I answer: in a somewhat playful feminist act of resurrection, Eliza Haywood, the voice that reasserts itself into the text, occupying some 60 pages of the 1740 continuation of Roxana.

In all of the scholarship that has been written about J.M. Coetzee's 1986 novel Foe and its various intertexts, which include Daniel Defoe's Roxana and Robinson Crusoe, ${ }^{1}$ no one has ever suggested that perhaps the story that could fill the "gap" between Roxana and Foe could be the literal story of the plagiarism, appropriation, and dismissal of $18^{\text {th }}$ century author Eliza Haywood. Haywood, whose Love in Excess (1719) along with Defoe's Robinson Crusoe (1719), and Jonathan Swift's Gulliver's Travels (1724) were "the early $18^{\text {th }}$-century's best-selling fictional narratives" (Rosenthal, 2007), now occupies a space in the history of the novel where until recently, the only thing that anyone knew definitively about her was that she died on February 25, 1756. Just as Foe revises Susan Barton's story in Coetzee's novel, changing her from castaway to whore who abandons her children (as Defoe's Roxana does), Haywood scholars have worked to address the revision and effective erasure of Haywood's story by Alexander Pope and Richard Savage in their construction of her as a wayward woman and mother of two illegitimate children. ${ }^{2}$

In this essay, I posit that if we push back against the idea of sole authorship of any novel and consider instead that such an idea is a myth based on a patriarchal and monologic notion of the form of the novel, we can read the authorial predicament of Foe's Susan Barton as a fictionalization of the plight of the historical Eliza Haywood and other female authors of her time, and, further, we can read the historical Haywood as one of the many authors (and narrators) of Coetzee's Foe, particularly as Coetzee's work requires that we view him as one of the (many) authors of Defoe's Robinson Crusoe and Roxana. Such an act of pushing back against literary history and women's place within it complicates all kinds of things in

\footnotetext{
${ }^{1}$ Josephine Dodd has also suggested that in Foe Adrienne Rich's poem "Diving into the Wreck" also constitutes an intertext, albeit one that Coetzee appropriates.

${ }^{2}$ See Kathryn R. King's A Political Biography of Eliza Haywood (2016) for a careful explication of the way that Haywood's persona has been shaped and reshaped.
} 
what I hope are productive ways, including extant analyses of Coetzee's work's feminist (or anti-feminist) postcolonial (or postmodern) project and allows for a larger discussion about the history-and colonizing impact-of the English novel, particularly the colonizing impact of Defoe's novels. Coetzee has said that Foe "if it is about any single subject, is about authorship: about what it means to be an author not only in the professional sense (the profession of author was just beginning to mean something in Daniel Defoe's day) but also in a sense that verges, if not on the divine, then at least on the demiurgic: sole author, sole creator" (Coetzee, 2006, para. 26, emphasis mine). By rendering Susan Barton's story visible to us-despite Foe's erasure of Barton from his castaway narrative-Foe requires that we question the idea of the "sole author" of any novel and that we question the construct of the novel as literary mode of appropriation, exploitation, and colonization.

During her writing career (1719-1756), British author Eliza Haywood wrote over 60 novels and romances containing the greatest number of disguising heroines in eighteenth-century fiction (Schofield, p. 24). As a playwright, performer, Tory political pamphleteer, and novelist, Haywood refused to remain in the private sphere to which women of her station were generally relegated and achieved popularity despite the stigma associated with women who wrote for profit. But according to Karen Hollis, although Haywood was given the title "Arbitress of Passion" by her contemporaries and although "she outsold nearly all of her rival novelists in the early $18^{\text {th }}$-century, [she] has been relegated by critical posterity to a decided third place in the 'fair Triumvirate' consisting of Aphra Behn, Delariviere Manley, and Haywood herself" (Hollis, 1997, p. 43). But Haywood was such a significant master of the craft that Paula Backscheider asks why "Defoe, and not Defoe and Haywood, is credited with originating the realist novel?" (1996, pp. 23-4). Haywood it seems, understood the reasons. She asserts, if the writings of women "are considerable enough to make any Figure in the World, Envy pursues her with unweary'd Diligence; and if, on the contrary, she only writes what is forgot, as soon as read, Contempt is all the Reward" (qtd. in George F. Whicher's The Life and Romances of Mrs. Eliza Haywood).

The exclusion of Haywood's work from the English literary canon, according to Backscheider and Richetti (1996), is based in part on the fact that women's literature was viewed as "disposable entertainment" (p. xi) aimed at a less educated audience than literature written by men. Unlike her male contemporaries, until the 1990s, when she was resurrected by feminist scholars, Haywood, derided by Alexander Pope in his Dunciad (2009), had vanished into obscurity. In order to undermine her art, Pope, with as much misogyny as he could muster, attacked Haywood's morality in his Dunciad. For Pope, Haywood becomes a prize to be won in a literal pissing contest:

See in the circle next, Eliza placed,

Two babes of love close clinging to her waist;

Fair as before her works she stands confess'd,

In flowers and pearls by bounteous Kirkall dress'd.

The goddess then: 'Who best can send on high

The salient spout, far-streaming to the sky; 
His be yon Juno of majestic size,

With cow-like udders, and with ox-like eyes.

This China Jordan let the chief o'ercome

Replenish, not ingloriously, at home.' (Pope, 2009)

In a letter to a female friend, Jonathan Swift called her "a stupid, infamous, scribbling woman,"3 even as he admitted to never having read her work. By collapsing "the binary terms of personal and aesthetic judgment" (Blouch, 1991, p. 540), Pope conflated Haywood's supposedly illegitimate childre ${ }^{4}$ and her writing, thus rendering it "illegitimate" as well. As King notes, the Dunciad's depiction of the "fore-buttocked 'Eliza' with 'sagging breasts' and 'babes of love' at her waist . . . comes to us today fitted out with a sexually scandalous past and two illegitimate children" (King, 2016, p. 5), but according to Christine Blouch, the present day belief that Pope hurt Haywood's career is incorrect: "Haywood was not only not silenced by Pope, but capitalized on her post-Dunciad notoriety during the early years of the decade" (Blouch, 1991, p. 541) as both an actor and as a playwright.

In "The 1740 Roxana: Defoe, Haywood, Richardson and Domestic Fiction," Nicolas Seager (2009) examines the lengthy plagiarism of Eliza Haywood's 1722 novel The British Recluse in the 1740 continuation of Daniel Defoe's 1724 novel Roxana. According to Seager, the volume that Defoe and Haywood share, "the 1740 Roxana, is an attempt to shore up brands of fiction that subvert the ideological values of the incipient domestic novel, initiated noncoincidentally in November 1740 with the publication of Samuel Richardson's Pamela, or Virtue Rewarded' (p. 104). The 1740 continuation is one of at least seven other rewritings that added to Defoe's original novel, using Defoe's somewhat abrupt ending as an opportunity to further (or change) the moral imperative of the original while also generating further revenue from the sale of these subsequent various editions. Seager notes that the

1740 Roxana is not just a work of many hands in the book trade; it is a work of many authors, some of whom were dead in 1740 and some of whom can be identified. Consequently the 1740 Roxana adds to our understanding of literary theft, book production, and formal expectations in the early eighteenth century. (2009, p. 359).

Further, his recognition that "the critical neglect of the Roxana continuations betrays our default recourse to the author as the site and guarantor of meaning" $(2009$, p. 370$)$ asks that readers push back against the notion of the "sole authorship" that we tend to ascribe in the case of the novel as artifact: partial reproduction without attribution was allowed under copyright law in 1740, and because none of the seven texts that make up the 1740 Roxana appears in its entirety, no law was broken in the creation of this continuation. In fact, I assert that the text constitutes a conversation, a dialogic investigation of the original. While Haywood played no part in the incorporation of her work in the 1740 Roxana, her work's intrusion into the text, like Coetzee's over two centuries later, situates Defoe, Haywood, and

\footnotetext{
${ }^{3}$ Elrington Ball, F. (Ed.). (1913). The Correspondence of Jonathan Swift, DD. London: Oxford

${ }^{4}$ King has questioned whether Haywood had children at all and argues against Christine Blouch's reading of her possible children as illegitimate.
} 
Coetzee as authors of Roxana.

According to Robert J. Griffin, "the story of Haywood's Cleomira and Belinda [from The British Recluse], both of whom have been seduced and abandoned by the same gentleman ... . [functions] as a cautionary tale" (p. 5) in the 1740 Roxana. However, in Haywood's original text, the British recluse (Cleomira) and her friend Belinda choose to live "in a perfect Tranquility, happy in the real Friendship of each other" (Haywood, 1996, p. 224) at the novel's end. While Haywood's original narrative's "happy" ending is subverted in the 1740 retelling, such subversion-and J.M. Coetzee's exposure of the ways that male authors' texts subverted women's attempts at autonomy-places the authorship of the original form of the English novel in the space of a war between the sexes: is the originator of the English novel Defoe, or is it Haywood? If we want to ensure that Haywood didn't "father" the English novel, one way to make certain would be to write her out of the "seminal" narrative of English authorship-a narrative dependent upon acceptance of Defoe's Robinson Crusoe as universal, of Crusoe himself as an Everyman (Carter, 2010, p. 27), the colonizer of a foreign land and the effective master of a black man, Friday.

In writing about Foe, Spivak examines the colonizing mission of the work, asking that we as readers distinguish between "internal colonization'-the patterns of exploitation and domination of disenfranchised groups within a metropolitan country like the United States or Britain-and the colonization of other spaces, of which Robinson Crusoe's island is a 'pure' example" (Spivak, 1990, p. 2), and she discusses the way Coetzee's novel troubles the notion that Crusoe can ever be read as a marginalized figure: Foe

reopens two English texts in which the early eighteenth century tried to constitute marginality: Daniel Defoe's Robinson Crusoe (1719) and Roxana (1724). In Crusoe, the white man marginalized in the forest encounters Friday the savage in the margin. In Roxana, the individualist female infiltrates nascent bourgeois society. In Coetzee's novel, a double gesture is performed. In the narrative, Roxana begins her construction of the marginal where she is, but when her project approaches fulfilment, the text steps in and reminds us that Friday is in the margin as such, the wholly other. (1990, p. 4)

Further, Abdel Karim Daragmeh and Ekremah Shehab (2012) note the importance of literary works that write back to and against colonial literary narrative as well as against the colonial force of the very form of the British novel by questioning "the status of both speech and writing as the only means of telling history in the European tradition:" "the writing and rewriting of colonial and postcolonial stories are important because a) they counter colonial voices in the European novel; b) they fill gaps in the history of colonialism" (2012, p.183). The means by which Coetzee's novel problematizes Robinson Crusoe, a text that Linda Carter refers to as "not merely . . . a classic . . but a classic that is considered as . . . arguably the foundation stone-of the canon" (2010, p. 27), is by embedding and superimposing various accounts, "with constant displacements from the experienced to the written, from the recounted to the imagined, from the real to the dream. As a palimpsest, traces of the former copy remain" (p. 30). Coetzee becomes the parrot stunned and captured by Crusoe on the island, speaking back to him via the mimicry of a postcolonial perspective 
and intelligence unavailable to Defoe; Coetzee repeats Defoe's words to him, but this is repetition with a difference.

\title{
Foe's Third Narrative Space: Plagiarism and Omission
}

\begin{abstract}
Even at his best, his island parrot, the better loved of the two, spoke no word he was not taught to speak by his master. How then has it come about that this man of his, who is a kind of parrot and not much loved, writes as well as or better than his master? (Coetzee, 2003, p. 15)
\end{abstract}

The parrot that serves as a precursor for Friday in Defoe's Robinson Crusoe-a creature tamed and taught to speak -is completely absent from Susan's narrative of the island in Foe. But as Coetzee allows in his 2003 Nobel Prize acceptance speech "He and His Man," Defoe is the parrot to Crusoe. According to Mark Sanders, "Character has exchanged places with author. The pathos of this displacement-and thus of Coetzee's lecture-lies in the fact that Robinson Crusoe writes out of solitude" (2009, p. 40). Crusoe's man is not "his man Friday," but in Coetzee's speech, the man is the author himself, the voice that parrots back Crusoe's story, and that story, as we know, was written by Daniel Defoe. And Coetzee parrots Crusoe as spoken by Defoe. Who is the author, then, of "He and His Man"? In Foe the story of the island that Susan Barton tells is contra-factual (if something can be contra"factual" with regard to fiction) to Defoe's expansionist colonial narrative in Robinson Crusoe, but it is Susan's story, parroted by Coetzee. The Female Castaway, the work that Susan wants to be written by Foe, appears before us fully inscribed by Coetzee-even though Foe refuses to write Susan's story, choosing instead to write Roxana and, in so doing, turning Coetzee's Susan Barton into Daniel Defoe's eponymous heroine. So, again, whose story is Susan's? Defoe's (the original author) or Coetzee's (the deconstructionist) or someone else's entirely? If we count, as I do, Eliza Haywood as one of the authors of Roxana, is it hers? Susan searches for her lost daughter in Bahia, but she eventually abandons hope and embarks for Lisbon on the ill-fated voyage that brings her to the island of the reticent Cruso, face to face with the voiceless Friday. At the center of this narrative is a woman's desire to tell her story and to somehow coerce Friday to tell his. Susan's story is the story Cruso does not care to record and that Friday cannot tell because his tongue has been cut out, according to Cruso, by slavers who are also cannibals and perhaps "hold the tongue to be a delicacy" (Coetzee, 1986, p. 23). After she is rescued, Susan chooses to tell her story to Foe, the "author who had heard many confessions" (p. 48), and Foe's insistence upon creating a narrative of maternal reunion in spite of Susan's denunciation of a narrative that "traduces [her] account" (Attwell. 1993, p. 110), essentially revises her character in order to assert patriarchal control over her sexuality, forcing her to become, in some sense, Defoe's Roxana, even as she resists these revisions.

As I have already noted, women have had a difficult time of writing themselves into history in terms beyond their bodily value, no matter how well they may have been received by the public during the time they were writing-and Coetzee's novel can certainly be read as an indictment of that reality, even as Susan succeeds via the insistence of "her man," in this case Coetzee, author-but hardly sole author-of Foe. In Defoe's Robinson Crusoe, the 
sole mention of women is when Crusoe tells the audience that after he returns to England, he sends seven women "for Service, or for Wives to such as would take them: As to the English men, I promis'd them to send them some Women from England, with a good Cargoe of Necessaries, if they would apply themselves to Planting, which I afterwards perform'd" (1998, p. 220). Rosenthal notes that these women constitute "metropolitan detritus" (2007, p. 10), excess women who might serve as prostitutes for Crusoe's budding colonial enterprise. Similarly, Susan, like the story that she attempts to tell, functions as an excessive woman, an item for male consumption and as inspiration for male writerly creativity who serves, for Foe, no other purpose: she sleeps with him, serving as the muse for his subversion of her story. After the two have sex, he says, "a bracing ride," to which she responds, "it's always a hard ride when the muse pays her visits ... she must do whatever lies in her power to father her offspring" (1986, p. 140).

\section{The 1740 Roxana and the Commodification of Plagiarism}

I saw abundance of parrots, and fain I would have caught one, if possible, to have kept it to be tame, and taught it to speak to me. I did, after some painstaking, catch a young parrot, for I knocked it down with a stick, and having recovered it, I brought it home; but it was some years before I could make him speak; however, at last I taught him to call me by name very familiarly. (Defoe, Robinson Crusoe)

As I have already discussed, Defoe's Robinson Crusoe and Roxana are Foe's primary intertexts, both of which are born of Susan Barton's The Female Castaway. As Nicholas Seager (2009) notes, "the rise in its critical fortunes over the last forty years has seen Daniel Defoe's Roxana (1724) . . . take a place of prominence in the history of the eighteenthcentury novel" (p. 357). Defoe's Roxana, told from the first-person perspective of a woman named Susan - later Roxana, a name given during the period to stage performers - tells the story of a woman abandoned by a husband who squanders her fortune, leaving her to become a courtesan. Similarly, much contemporary speculation about Eliza Haywood focuses on the idea that, rather than leave her husband, her husband abandoned her. In Roxana, Susan becomes Roxana at a masquerade: "in less than half-an-hour I returned, dressed in the habit of a Turkish princess" (p. 264). Because masquerades allowed participants a degree of sexual social freedom during a time when women's roles were becoming less public and more rigidly defined, it is not surprising that Haywood, like Defoe, utilized the trope of the masquerade in their fiction. On the one hand, Terry Castle claims that Haywood and other writers of popular fiction "quickly came to exploit the masquerade's sensational associations with sexual license and libertinage" (p. 3), while on the other hand, Mary Anne Schofield asserts that the masquerade topoi allows the fictional heroine to embody a self that is antithetical to her real self, "thus providing a psychologically necessary outlet for female frustration" (1990, p. 24). Schofield further ascribes to the disguise narrative the psychologically productive work of allowing female authors to undertake a type of "double writing" through which the creation of the romance functions to mask their own "feminist, aggressive intentions and to unmask the facile and fatuous fictions they are supposed to be writing as members of the weaker sex" (p. 24). During her lifetime, Haywood was well known for her masquerade narratives, which allowed her female protagonists to try 
on various identities. Further, Defoe's Roxana is so-named because of a masquerade, while Coetzee's Susan unmasks Defoe, the male author who would layer identities upon her without her consent.

Defoe's hurried and ambiguous ending of Roxana has Roxana, recently married to a man who loves her and whom she loves in return, exposed to her husband the wayward life she has led; he dies soon thereafter, leaving Roxana to repent. The ending left the work open to various revisions, additions, and rewritings; Seager (2009) points to six such editions, those published in 1740, 1745, 1750, 1755, 1765, and 1775: "A number of these splice a new ending onto Defoe's text, either rewarding the penitent prostitute for her reformation or punishing her marital and maternal transgressions in the original novel" (2009, p. 357). The 1740 version cuts the final paragraph of the original novel and adds 60 pages of Eliza Haywood's The British Recluse as well as plagiarised sections of William deBritaine's 1697 text Humane Prudence. Just as Foe wrestles Susan Barton's story away from her, forcing her into the role of Roxana and not her self-proclaimed female castaway, the later and unknown transcriber of the 1740 Roxana has taken Susan/Roxana's narrative away from Defoe, rewriting her as a caring mother, undermining Defoe's status as author, and challenging his narrative of her mourning, penance, and piety. Feminist reclamation or no, the female protagonist is not punished for her transgressions and is granted agency in her life after her husband's death. After the lengthy section of Haywood's The British Recluse "things then pick up with Roxana narrating her final days: widowhood, retirement from the world, seeing her daughter marry the son of her Quaker friend, and delivering lengthy tracts of worldly advice to one of the sons whom the reader will remember she abandoned at the start of Defoe's novel" (Seager, 2009, p. 359).

Haywood's position in British literary history is telling with regard to the ways that women were allowed to be granted status as authors during the $18^{\text {th }}$ century. As Juliette Merritt notes, "women were permitted to write, but with certain restrictions" (p. 4); Haywood's early work was perceived as too racy - at least until relatively recently - to allow her membership in the narrative of the history of the novel, and it has been predominantly on the basis of her later "respectable novels of domestic sensibility" (p. 4) that she has gained entrance. Kathryn King notes that moreso than other literary figure from the period, "the Haywood we know, or think we know, is constructed out of the malignity of her enemies and they turn out to be fewer in number than we imagined" (p. 6). The revision of Haywood from licentious to respectable author of domestic fiction is in many ways a narrative that seeks to distance her literary significance from her earlier amatory work. But that work is extremely important for many reasons, not the least of which is its insightful rendering of gender roles and expectations and, more importantly, its challenges to them.

In The British Recluse, the text that shows up grafted onto the 1740 rewriting of Defoe's Roxana, two women, Belinda and Cleomira, bond over their shared pain and potential ruin at having lost their virtue to the same man, the rakish Lysander. After her father dies and leaves Cleomira and her mother destitute, Cleomira realizes that "it was time for me to learn to play the good Housewife, and forget that there ever were such Things as Balls, Plays, 
Masquerades, or Assemblies." But she does attend one fateful ball, where she meets Lysander. After she is undone, Cleomira fakes her own death and goes to live as a recluse - a masquerade that allows her, however solitary, at least control over her own life. When she and Belinda discover that they have been wronged by the same man, their friendship is nearly destroyed, but they come to realize that their love for each other is more real and valuable than their feelings for Lysander-and this is one of the markers of Haywood's early amatory fictions: women work to create previously nonexistent homosocial spaces in which they help each other out of trouble that has been caused to them by men. At the end of the novel, the two women choose to live "in a perfect Tranquility, happy in the real Friendship of each other" (p. 224). In Haywood's work, women come to know more about themselves and about other women through their tendency to love without reserve-even as such love will leave them without a recognized place within acceptable society. Nonetheless, Haywood's work also, as is the case with The British Recluse, creates a space for women to exist in community with each other via the performative choices they makethe disguises they don and the alliances that they form with one another.

In Coetzee's novel, Susan is granted no such community of women, but that exclusion is overdetermined as a misogynist enterprise designed to necessitate her exclusion. Foe asserts that she must do whatever she can to "father her offspring" as Susan cannot give birth to literary offspring on her own; she is a woman, incapable of fathering anything-and, of course, the genre of the novel is a male contrivance, a form from which she is banished, unless she chooses to function as a muse to engender male creativity. Sue Kossew reads Coetzee's project as feminist, noting that "Coetzee's choosing to 'write back' to Defoe is seen to relate to Defoe's tendency to exploit women's stories, so that many parallels are drawn between Susan and both Moll Flanders and Roxana" (p. 17), and M. Gaye et al. are in agreement with Kossew when they claim that "the introduction of female gender into the Crusoean world [a world that they claim is highly homoerotic] signals a provocative departure from a literary heritage and Coetzee's intention to settle accounts with Daniel Defoe" (p. 132). In this sense, one can read Coetzee's project as feminist revisionism, a critique of the male appropriation of women's writing presented through Coetzee's appropriation of Defoe's "master narrative," a narrative, in Coetzee's telling, that "belongs" to Susan Barton, and, through her, Eliza Haywood, even as she grows increasingly uncertain of her authority; as Susan says to Foe

In the beginning I thought I would tell you the story of the island and, being done with that, return to my former life. But now all my life grows to be a story . . I thought I was myself and this girl a creature ... speaking words you made up for her. But now I am full of doubt ... Who is speaking me? (Coetzee, 1986, p. 133)

\section{Haywood's Parrot and Resistance of the Master Narrative}

A very agreeable young Lady at Epsom, having made Complaint that an impudent Parrot on Clay-hill, whenever she happens to pass by, is always bawling, When did you see Captain Thumper, Oh! the dear Captain, the pretty, pretty Captain, till she was forc'd to remove her Lodgings, the she knows not, nor ever heard of any such Captain. The Gentleman believes the Parrot meant her no Affront, humbly 
begs her Pardon, and henceforward, Poll shall have less Victuals than formerly, that he may not be so very Pert, and be hung next to the Garden instead of the Street. (Haywood, The Female Tatler, 1709, as cited in Powell, 2008, p. 63)

Who indeed is speaking Susan Barton in Coetzee's Foe, in the 1740 continuation of Roxana? I want to move into the $21^{\text {st }}$ century to assert that postmodernism has fully and finally undermined the notion of sole authorship of the novel as metafictional reworkings of so-called master narratives point consistently (as does Foe) to their status as artifacts dependent upon the existence of other artifacts and on the myth of British colonial superiority and on the silencing of female writers like Haywood. Further, the publication process-with its dependence upon editors, proofreaders, translators, and reviewers-necessarily ensures the polyphonic nature of the novel, of the speaking back to, speaking over and in tandem with, and repeating verbatim but with an inflection, whether or not the novel references these other voices or not. The erasure of Susan Barton's story by Foe occurs in a postmodern work of metafiction (Coetzee's Foe), but that erasure simultaneously writes her story into being, just as the grafting of Eliza Haywood's The British Recluse onto the 1740 Roxana ensures that Haywood constitutes a presence, as author writing against Defoe's colonial literary project. Haywood was extremely aware of the challenges and confrontations women faced as writers and publishers, as she notes in the guise of "Phoebe Crackenthorpe, a lady that knows everything," contributor to Haywood's Female Tattler, a publication that circulated from 1709-1711. As Manushag N. Powell notes, the "parrot note" that precedes this section of my essay

demonstrates a number of connections among women, speech, periodicals, and parrots. Two issues stand opposed to each other: women, as publishers, authors, and readers, were indispensable contributors to the periodical scene in eighteenthcentury England. However, professional authorship was nonetheless imagined to be a matter for men, at least at its best. Therefore, when the feminine is invoked in discourses of periodical authorship, it is most often a vehicle for complaint: the idea is that periodicals are so proliferate and so vapid as to mimic women's speech, with gossip masquerading as didacticism. (2008, p. 63)

Haywood's parrot note asserts, via satire perhaps too subtle for many readers to understand, that "valued for its beauty as well as ability, the parrot was renowned for speaking articulately, but without sense or discrimination, and for this reason became a common deprecatory metaphor for threatening figures of alterity like social climbers, racial 'others,' and women who speak out or write improperly," and Haywood later created another albeit short lived periodical in 1746, "The Parrot, with a Compendium of the Times . . an exception to the misogynistic parrot tradition, wherein she cleverly invokes the talking parrot in a genre that is already specifically enabled by the metaphor of the female voice" (Powell 2008, p. 64). Haywood understood and embodied Crusoe's parrot, the trapped animal with the ability to speak, but she also embodied the mimicry of the marginalized speaker, the observant and canny ventriloquist, the wit who speaks truth with a subtlety that might be mistaken for mere repetition by the men who seek to define her.

Because of Susan Barton's story, Daniel Defoe is no longer definitively the author of Robinson Crusoe; because of the 1740 continuation of Roxana, he now must share 
authorship with J.M. Coetzee and with Eliza Haywood. Furthermore, Susan Barton's story in Foe serves to illustrate the plight of $18^{\text {th }}$ century female writers like Eliza Haywood, whose literary production was viewed by her male contemporaries as immodest-to the point that the prolific nature of her writing career was rhetorically conflated in Pope's Dunciad with prostitution-just as Susan is turned into the "whore" Roxana by Foe in Coetzee's novel.

In what I hope can now be read as an explicit critique of the production of literary fictionparticularly during the $18^{\text {th }}$ century, a period when women's texts were derided and the British Empire's colonial project was at its peak-Coetzee further undermines the reader's ability to determine who is subject and who is author, essentially who is speaking whom in part four of the novel, when the narrative voice shifts from Susan to two unknown narrators, both of whom enter Susan's story to find Cruso, the captain, and Foe indistinguishable from one another and, like Susan, dead. The only character whose body is still warm is Friday, and the narrator(s) press "a fingernail between the upper and lower rows" (p. 154) of his teeth, "trying to find a way in" (p. 157) to the black hole of his mouth. Ultimately, it is Friday's wordless story, "the sounds of the island" and the "slow stream, without breath, without interruption" (p. 157) that emerges and devours the other narratives by displacing Susan/ Coetzee's quests for meaning, signifying instead in a place where "bodies are their own signs" (p. 157); Friday is the true subject of the story, the one who has not yet spoken its truth. The question of who narrates this part of the novel after all the other story tellers in the narrative are dead, their "skin, dry as paper ... stretched over their bones" (p. 153) or their bodies "fat as pigs ... puckered from long emersion" (p. 157) is open to speculation, and scholars have posited that the voice in question is not Susan's or Foe's but rather Coetzee's. I disagree. I contend that that voice belongs to Eliza Haywood, the female author written out of and then back into the story of the history of the novel. The unknown voice at the end of the novel is the voice that challenges our conceptions of the novel as an artifact with a singular male author, that, instead, asks that we recognize the polyphonic nature of pastiche, the novel as dialogic endeavor, the text as inhabited by many women who wrote back.

\section{References}

Attwell, D. (1993). J. M. Coetzee: South Africa and the politics of writing. Berkeley: U of California $P$.

Backscheider, P. R., \& Richetti, J. J. (Eds.). (1996). Popular fiction by women 1660-1730: An anthology. Oxford, Clarendon Press.

Barker-Benfield, G. J. (1992). The culture of sensibility: Sex and society in eighteenthcentury Britain. Chicago, $\mathrm{U}$ of Chicago $\mathrm{P}$.

Blouch, C. (1991). Eliza Haywood and the romance of obscurity. Studies in English Literature 1500-1900. 31(3), 535-51.

Carter, L. (2010). Contaminated copies: J.M. Coetzee's Foe. In M. Gonzalez (Ed.), Generic instability and identity in the contemporary novel (pp. 26-33). Newcastle upon Tyne, Cambridge Scholars.

Castle, T. (1986). Masquerade and civilization. Stanford: Stanford UP.

Coetzee, J. M. (1986). Foe. New York: Penguin.

Coetzee, J. M. (2003). He and his man [Nobel Lecture]. 
Coetzee, J. M. (2006, January 26). Speaking in Tongues. The Australian (Weekend Review), pp. 4-6.

Daragmeh, A. K., \& Shehab, E. (2012). Signs tell their own stories: Rethinking the status of writing and speech in J. M. Coetzee's Foe. Matatu: Journal for African Culture and Society. 41, 183-196.

DeFoe, D. (1998). Robinson Crusoe. Mineola, New York: Dover.

DeFoe, D. (2008). Roxana, the fortunate mistress. Oxford: Oxford UP.

Elrington Ball, F. (Ed.). (1913). The correspondence of Jonathan Swift, DD. London: Oxford Haywood, E. (1996). The British recluse. In P. R. Backscheider \& J.J. Richetti (Eds.), Popular fiction by women 1660-1730: An anthology (pp. 153-226). Oxford, Clarendon Press.

Hollis, K. (1997). Eliza Haywood and the gender of print. The Eighteenth Century 38(1), 4362.

King, K. (1993). A political biography of Eliza Haywood. New York: Routledge.

Kossew, S. (1993). Women's words: A reading of J. M. Coetzee's Women narrators. Span 37(1), 12-23.

Pope, A. (2009). The Dunciad. New York: Routledge, 2009.

Powell, M. N. (2008). Parroting and the periodical: Women's speech, Haywood's Parrot and its antecedents. Tulsa Studies in Women's Literature 27(1), 63-91.

Rosenthal, L. (2007). Eliza Haywood: Discrepant cosmopolitanism and the persistence of romance. Nineteenth-Century Gender Studies 3(2), 26 paragraphs.

Sanders, M. (2009). The writing business: He and his man, Coetzee and Defoe. Journal of Literary Studies [Tydskrif vir Literatuurwetenskap] 25(4), 39-50.

Seager, N. (2009). Prudence and plagiarism in the 1740 continuation of Defoe's Roxana. Library: The Transactions of the Bibliographical Society 10(4), 357-371.

Turk, T. (2011). Intertextuality and the collaborative construction of narrative: J.M. Coetzee's Foe. Narrative 19(3), 295-310.

Schofield, M. A. (1990). Masking and unmasking the Female Mind: Disguising Romances in Feminine Fiction, 1713-1799. Newark: U of Delaware P.

Spivak, G. (1990). Theory in the margin: Coetzee's Foe reading Defoe's Crusoe/Roxana. English in Africa 17(2), 1-23. 